\title{
The implications of the political situation in the UK for firms:
}

\section{A Bourdieusian perspective}

Prof. Martyna Śliwa, email: martyna.sliwa@essex.ac.uk (corresponding author)

Essex Business School, University of Essex, Wivenhoe Park, Colchester, CO4 3SQ

Dr Ron Kerr, email: ron.kerr@ed.ac.uk

University of Edinburgh Business School, University of Edinburgh, 29 Buccleuch Place, Edinburgh, EH8 9JS

Prof. Sarah Robinson, email: sarah.robinson.2@glasgow.ac.uk

Adam Smith Business School, University of Glasgow, West Quadrangle, Gilbert Scott Bdg, University Avenue, Glasgow, G12 8QQ

\begin{abstract}
The political situation in the UK poses unprecedented challenges for firms as well as management and organization studies (MOS) scholars. In this short paper, we encourage MOS researchers to consider the French sociologist Pierre Bourdieu's conceptual framework, in particular, his key concepts of field, capital, habitus and hysteresis, as a lens to analyse the multifaceted implications for firms of the current political circumstances in Britain. We explain how a Bourdieusian perspective can help researchers challenge taken-for-granted assumptions about the interconnections between politics and business in the context of Brexit, and can assist in generating valuable insights regarding the situation of firms operating in the UK in the context of the present changes in the environment.
\end{abstract}




\section{Introduction}

Political uncertainty in the UK is causing other types of uncertainty and affecting the business environment both within and outside Britain. As a result, management and organization studies (MOS) scholars are faced with the task not only of following the development of these events, but also of conducting research that is practically relevant to firms and other organizations. For MOS research to be relevant to firms in the current climate, it needs to be able to inform decision-making and strategy. In particular, it needs to elucidate, conceptually, the links between the macro-level of politics, the meso-level of firms and the micro-level of individual actors. Further, through reference to empirical issues and challenges faced by organizations, it needs to be able to explain the implications of political actions for firms. In this short paper, we would like to encourage management scholars to consider the French sociologist Pierre Bourdieu's conceptual framework as a lens through which to analyse the multifaceted interconnections between different levels of analysis and domains of social activity. In particular, we would like to draw attention to Bourdieu's key concepts of field, capital, habitus and hysteresis. In the remainder of the paper, we briefly illustrate the relevance of these concepts for understanding the implications of the political situation in the UK for firms.

\section{The UK's political situation and firms' responses to it}

Ever since the result of the Brexit referendum in June 2016, the UK's political situation has been uncertain, both internally and with regard to the country's future place within the global geopolitics. The current Prime Minister Boris Johnson's decision to prorogue the Parliament in early September 2019, which was ruled unlawful by the Supreme Court later that month, further exacerbated struggles over understanding what constitutes a legitimate approach to decision-making in the political sphere: fulfilling the will of the Parliament as democratically chosen to represent the society, or honouring the people's will as directly expressed through plebiscite. It also gave rise to concerns about the UK PM's commitment to following the 
country's democratic processes. These concerns have not been diminished by the result of the December 2019 General Election, in which Johnson's Conservatives were returned with an overall majority.

The political situation in the UK, and the lack of clarity in relation to Brexit, have posed unprecedented challenges for firms, exacerbating an already existing instability in the wake of the 2008 Global Financial Crisis. In the first place, this is because of a range of developments that have damaged the UK's reputation as a country that is politically stable and economically predictable: in other words, a 'pragmatic and sensible place to do business' (Goodman, 2019). Second, the political events of the past three years have introduced a high level of uncertainty to the UK's business environment, jeopardising firms' ability to predict and plan for the future, already difficult in the post-2008 period. Although it is not known how severely the UK's economy might suffer post-Brexit, there is a consensus among industry leaders and influential economic commentators that 'no one is ready for no-deal Brexit' (Wallace and Foster, 2019), and that it would be bad for the country, potentially leading to recession (The Economist, 2019).

Membership of the European single market and customs union has meant that UKbased firms have been able to benefit from EU-wide freedom of movement with regard to goods, services and people, manifested in the absence of border checks, a harmonised VAT system and the lack of obligation to pay customs duty, as well as the ability to hire employees from the entire EU area. In addition, the UK's status as an EU member country has made it clear to both British and international businesses what the rules of operating in the country, logistically as well as financially, are. As the current arrangements are set to change following Brexit, business leaders have to take decisions in response to environmental unknowns such as the legal regulations surrounding UK-based firms' operations across international supply 
chains, the ability to employ EU nationals, or the unpredictable volatility of Sterling and its impact on costs and profits.

Unsurprisingly, firms have tended to respond to this situation of high uncertainty and have done so in three ways. To some, the inability to predict the future and the possibility of a disorderly Brexit, which remains a threat after the 2019 election, have resulted in postponing investment decisions (Cruise and Withers, 2019; Tetlow and Stojanovic, 2018). Many others - discouraged by the prospect of the lack of access to the EU market in the case of a no-deal Brexit, have been forced to relocate or are planning to relocate to a base within the European Union - such as Belgium, France, Germany, Ireland and the Netherlands (Dmitracova, 2019; Inman, 2019). Yet others, most notably hedge funds, have been reported as supporting a nodeal Brexit, seeing it as an opportunity to generate profits (Collinson, 2019). Indeed, according to Edgerton (2019), 'the capitalists who do support Brexit tend to be very loosely tied to the British economy'.

Whilst the responses of specific companies have been widely documented in general and sector media, a conceptually informed analysis of firms' decisions under current circumstances is yet to emerge from the MOS literature. To this end, we propose turning for inspiration to the works of French sociologist Pierre Bourdieu who has developed an insightful conceptual approach that allows for analysing the impact of crisis on different aspects of social and economic life, organizations and actors.

\section{A Bourdieusian perspective on the implications of the UK's political situation for firms}

Bourdieu's work stands squarely in the classical tradition of European sociology and addresses the problematic of how power operates in capitalist modernity. Bourdieu constructs an original synthesis and conceptual development of the work of Marx (forms of capital that go beyond the economic), Weber (social fields as social stratification), and Durkheim (the role of fundamental categories in constructing and imposing a vision of the world). Like Weber, 
Bourdieu also wants to know how authority comes to be taken for granted as legitimate, and drawing on the work of German philosopher Ernst Cassirer (1965), develops the concepts of symbolic power and symbolic violence to explain how domination is accepted by the dominated. Bourdieu also draws on the phenomenology of Merleau-Ponty in developing the concept of habitus in order to overcome the structural determinism/methodological individualism problem (Bourdieu 1967). In addition to the above, Bourdieu was also open to other intellectual currents, including, in relation to his theory of practice, Wittgenstein's 'language games' and Austin's 'doing things with words' (Bourdieu 1991).

According to Bourdieu, then, a society consists of a range of spheres that are characterised by their own unique organizing logics, principles and interests. Bourdieu (1984, p. 113) refers to these spheres as 'fields' and explains that they 'present themselves synchronically as structured spaces of positions (or posts) whose properties depend on their location in these spaces and can be analysed independently of the characteristics of their occupants'. Actors engaged in a given field struggle for a position in that field, using the resources they have at their disposal, which Bourdieu (1986) refers to as 'capital', distinguishing between different forms of capital, such as social, economic, cultural, and symbolic. Depending on the field, certain forms of capital afford the actors greater power than others. Altogether, the higher the volume of capital an actor possesses, the higher their position in the field. The most powerful actors in a field are able to dominate that field, for example through modifying and imposing its organizing principles and rules onto other actors. At the same time, each field interacts with other fields and is positioned in a hierarchical relationship to them (Bourdieu, 1984; Bourdieu and Wacquant, 1992).

Considered through a Bourdieusian lens, the political situation in the UK is an example of a crisis in the political field that is transposed onto the economic field and further, onto organizations and individual actors. In a situation of crisis, actors are faced with 'structural 
uncertainty' (Dobry, 1986/2009). Arguably, this is precisely the situation in which firms doing business in the UK have found themselves following the Brexit referendum, since, as Ancelovici (2019, p. 12) explains, structural uncertainty denotes 'the blurriness or disappearance of reference points and indicators on the basis of which actors normally evaluate situations, determine what is happening, anticipate the effects of their actions and the actions of other actors, and ordinarily calculate or construct strategies'. Importantly, every action that the actors take, including withholding from taking action, as in the case of firms delaying investment decisions, constitutes a course of action (Goffman, 1969) and has consequences for the actors.

What specific actors - be it politicians or firms' leaders - decide to do in a situation of crisis, is conditioned by their more durable and pre-established dispositions, assumptions, cognitive categories, and past experiences and practices, or, in Bourdieusian terms, their habitus (Bourdieu, 1980; Bourdieu and Wacquant, 1992). Bourdieu's conceptualisation of habitus, which captures the way that social structure and agency are mutually reproductive, is important for the understanding of both the processes underlying the current political situation in the UK, its structural determinants, and its implications for firms. It highlights the divergence between the habitus of powerful sections of the British political elites, still locally situated, and sections of the internationally mobile, delocalised, business elites. This, in turn, helps explain the reasons behind those sections of the political elites' support for Brexit, regardless of its likely detrimental consequences for businesses.

In the past, those studying elites commonly assumed the alignment of political and economic elites' interests, seeing members of these two types of elite as belonging to the broader category of power elites. The notion of the 'power elite' was introduced in C. Wright Mills' (1956, p. 4) classic work, The Power Elite, in which he outlined an understanding of the elite as individuals occupying 'pivotal positions $[\ldots]$ in command of the major hierarchies and 
organizations of modern society'. In Britain, members of power elites have traditionally shared a particular habitus, developed through privileged upper-class upbringing, attendance at one of 'Clarendon Nine', (formally) gender-segregated public schools, and university education undertaken predominantly at Cambridge, and - in particular in the case of political leaders Oxford universities. To illustrate this, Reeves and colleagues (2017) highlight the homogeneity of the background of British political elites by specifying that out of 54 UK Prime Ministers, $67 \%$ were educated in one of these nine 'Great Schools'. Up until now, graduates of one of the 'Clarendon Nine' schools are reportedly 94 times more likely to become members of the British elite than graduates of any other school in the UK. Importantly for the Brexit context, both David Cameron and Boris Johnson attended the most prestigious of the 'Great Schools' - Eton. In addition to developing future political leaders, these schools have been renown for preparing graduates for future top positions in British law, business, culture and the military.

As Jones (2015, p. 5-6) argues, the elite schooling of the British 'establishment' has had an important role in maintaining its 'cohesion' and 'solidity', built around 'common economic interests and a shared set of mentalities', concerned with 'protecting the concentration of wealth in very few hands'. In other words, over a long time - notwithstanding the differences both within and between these two groups - there have been close links between the political and economic elites in Britain. However, whilst up to the 1990s, there was a significant overlap between the political and economic elites in the UK, in recent years these two groups had become separated from each other (Hartmann and Lueg, 2017). This 'habitus alienation', manifested in 'lessening social similarities between managers and politicians' (Hartmann and Lueg, 2017, p. 28) has taken place as a result of globalising tendencies in the economic sphere, which have led to a situation where one third of CEOs in the UK are now of non-British origin, and where national manufacturing has shrunk to about $9 \%$ of GDP compared with close to $17 \%$ in 1990 (Macrotrends, 2019). Due to the decline in the ties and 
mutual influence between the domestic political elite and the much more internationalised business elite, 'big business' in the UK, which was predominantly anti-Brexit, was unable to prevent the Conservative Party's majority decision to vote for and support Brexit. A key implication of this 'habitus alienation' between members of the economic and political elites in the UK for firms' leadership in the present context is the need for firms' leaders to understand that the UK's political elites do not have it as the main priority to represent business interests, particularly in relation to productive capital, whereby, across all sectors, EU membership brings benefits to business. Therefore, in responding to the current political circumstances, businesses will need to adapt to the changing environment without assuming that the Conservative government is going to protect their interests.

In considering the implications of the UK's political situation for firms, it is also important to understand the diversity characterising the habitus of firms' leaders, and the consequences of this diversity for how they might respond to the changing situation in the business environment. In Bourdieu's view, not all actors have the same capacity to adapt their habitus in a situation of crisis. On the contrary, an external shock affecting a given field is likely to result in a gap between the new conditions and 'rules of the game' within the field and at least some actors' habitus. To refer to this 'mismatch' between the field - especially in a situation of crisis and fluidity - and actors' inertia that prevents them from adapting to it due to their dispositions and the past experiences that shaped their habitus (Ancelovici, 2019), Bourdieu uses the term 'hysteresis'. He argues that 'the hysteresis of habitus [...] is doubtless one of the foundations of the structural lag between opportunities and the dispositions to grasp them' (Bourdieu, 1972/1977, p. 83). What this means for firms, is that whilst some business leaders will be able to gradually adapt to the new conditions, others will not be capable of doing this, with detrimental consequences for the firms and themselves. In order to provide insights of relevance to practice, an important task of MOS scholars becomes investigating how firms' 
leaders use resources - or forms of capital - at their disposal as they strive to respond to the current circumstances.

\section{Conclusion}

In this short paper, we have argued for the application of Bourdieu's work to understand the implications of the current political situations in the UK for firms. Adopting a Bourdieusian perspective, in particular through reference to his concepts of field, capital, habitus and hysteresis, can help MOS researchers challenge taken-for-granted assumptions about the interconnections between politics and business in the UK, for example the idea that the Conservative party is 'the party of business' (Edgerton 2019), or that the UK business elite is monolithic rather than constituted of different fractions with differing interests (e.g. manufacturing, banking, finance, services). It can also assist in generating valuable insights regarding the situation of firms operating in the UK in the context of the present changes in the environment. For firms, this knowledge can be translated into specific strategies for using their resources - the forms of capital they have at their disposal - in a way that will help them survive and respond to the challenges they face in this uncertain environment.

\section{References}

Ancelovici, M. (2019). 'Bourdieu in movement: Toward a field theory of contentious politics', Social Movement Studies, DOI: 10.1080/14742837.2019.1637727.

Bourdieu, P. 1967. Postface to E. Panofsky, Architecture gothique et pensée scholastique. Paris: Les éditions de minuit.

Bourdieu, P. (1972/1977). Outline of a Theory of Practice. Cambridge, UK: Cambridge University Press. 
Bourdieu, P. (1980). Le Sens Pratique. Paris, France: Éditions de minuit.

Bourdieu, P. (1984). Quelques Propriétés des Champs. In P. Bourdieu (Ed.), Questions de sociologie (pp. 113-120). Paris: Éditions de Minuit.

Bourdieu, P. (1986). 'The Forms of Capital', in J. G. Richardson (ed.) Handbook of Theory and Research for the Sociology of Education, pp. 241-58. New York: Greenwood Press.

Bourdieu, P. 1991. Language and Symbolic Power. Harvard: Harvard University Press.

Bourdieu, P. and L. Wacquant (1992). Réponses: Pour une Anthropologie Réflexive. Paris: Éditions du Seuil.

Cassirer, E., 1965. The Philosophy of Symbolic Forms: Volume 1: Language.

Collinson, P. (2019). 'Short-selling: can hedge funds make a fortune from no-deal Brexit?', The Guardian, 30 September 2019, https://www.theguardian.com/business/2019/sep/30/short-selling-hedge-funds-fortune-nodeal-brexit-boris-johnson (accessed 7 October 2019).

Cruise, S. and I. Withers (2019). 'UK banks say investment slowing further ahead of Brexit', Reuters, 15 July 2019, https://uk.reuters.com/article/uk-britain-eu-banks/uk-banks-saybusiness-investment-slowing-further-ahead-of-brexit-idUKKCN1UA0VI (accessed 7 October 2019).

Dmitracova, O. (2019). 'Brexit pushes almost 100 firms to move to Netherland', The Telegraph, 27 August 2019, https://www.independent.co.uk/news/business/news/brexit-nodeal-uk-netherlands-company-relocation-a9080666.html (accessed 31 December 2019). 
Dobry, M. (1986/2009). Sociologie des Crises Politiques. Paris, France: Presses de Sciences Po.

Edgerton, D. (2019) Brexit is a necessary crisis - it reveals Britain's true place in the world, The Guardian, 9 October 2019, https://www.theguardian.com/commentisfree/2019/oct/09/brexit-crisis-global-capitalismbritain-place-world (accessed 31 December 2019).

Goffman, E. (1969). Strategic Interaction. Philadelphia, PA: University of Pennsylvania Press.

Goodman, P.S. (2019) 'For many British businesses, Brexit has already happened', The New York Times, 1 April 2019, https://www.nytimes.com/2019/04/01/business/british-businessbrexit.html (accessed 31 December 2019).

Hartmann, M. and K. Lueg (2017). 'Brexit: On the declining homogeneity of European elites - and on the importance of a domestic habitus in times of globalization', Culture, Practice and European Policy, 2, pp. 28-34.

Inman, P. (2019). 'One in three UK firms plan for Brexit relocation, IoD says', The Guardian, 1 February 2019, https://www.theguardian.com/politics/2019/feb/01/one-three-ukfirms-activate-plans-move-operations-abroad-no-deal-brexit-iod-survey (accessed 31 December 2019).

Jones, O. (2015). The Establishment: And How They Get Away With It. London: Penguin.

Macrotrends (2019) U.K. Manufacturing Output 1990-2019, https://www.macrotrends.net/countries/GBR/united-kingdom/manufacturing-output (accessed 31 December 2019). 
Mills, C.W. (1956) The Power Elite. Oxford: Oxford University Press.

Reeves, A., Friedman, S., Rahal, C. and Flemmen, M. (2017). 'The decline and persistence of the Old Boy: Private schools and elite recruitment', American Sociological Review, 82, pp. $1139-1166$.

Tetlow, G. and E. Stojanovic (2018). Understanding the Economic Impact of Brexit. London: Institute for Government.

The Economist (2019) 'Why predicting the impact of a no-deal Brexit is so hard', $25^{\text {th }}$ July: https://www.economist.com/britain/2019/07/25/why-predicting-the-impact-of-a-no-dealbrexit-is-so-hard. (accessed 31 December 2019).

Wallace, T. and P. Foster (2019) “"No-one is ready for no deal” Brexit in industry, government or the EU, warns CBI', The Telegraph, 28 July 2019, https://www.telegraph.co.uk/business/2019/07/28/no-one-ready-no-deal-brexit-industrygovernment-eu-cbi-warns/ (accessed 31 December 2019). 